\title{
A Dialogue of Sources: Greek Bourgeois Women and Material Culture in the Long 18th Century
}

\author{
Artemis Yagou
}

\section{The Context}

In the Ottoman-dominated Europe of the Early Modern period (17th to 19th centuries), certain non-Muslim populations, especially the Christian elites, defined their social status and identity at the intersection of East and West. The westernization of southeastern Europe proceeded not just through the spread of Enlightenment ideas and the influence of the French Revolution, but also through changes in visual culture brought about by western influence on notions of luxury and fashion. This approach allows a closer appreciation of the interactions between traditional culture, political thought, and social change in the context of the modernization or "Europeanization" of this part of Europe. ${ }^{1}$

The role of the "conquering Balkan Orthodox merchant" in these processes has been duly emphasized. ${ }^{2}$ The Balkan Orthodox merchant represented the main vehicle of interaction and interpenetration between the Ottoman realm and the West, bringing the Balkans closer to Europe than ever before. ${ }^{3}$ The gradual expansion of Greek merchants beyond local trade and their penetration into export markets is the most characteristic event of the 18th century in Ottoman-dominated Greece. ${ }^{4}$ This was triggered by political developments, more specifically the treaty of Küçük Kaynarca in 1774, the opening of the Black

1 LuxFaSS Research Project, http://luxfass.nec.ro, [accessed 30 May 2017].

2 Troian Stoianovich. "The Conquering Balkan Orthodox Merchant," The Journal of Economic History 20 (1960): 234-313.

3 Fatma Müge Göçek, East Encounters West: France and the Ottoman Empire in the Eighteenth Century (New York, 1987); Vladislav Lilić, "The Conquering Balkan Orthodox Merchant, by Traian Stoianovich. The Journal of Economic History, vol. 20, no. 2, June 1960, 234-313", Global History Review, March 2015, https://globalhistoryreview.wordpress.com/2015/03/21/the -conquering-balkan-orthodox-merchant-by-traian-stoianovich-the-journal-of-economic -history-vol-20-no-2-june-196o-pp-234-313/ [accessed 30 May 2017].

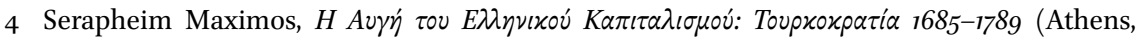
2008), 108. 
Sea to foreign navigation in 1783 , and the outcome of the $1788-92$ conflict with Russia which reduced the former political and diplomatic preponderance of France and created a forced rapprochement between the Ottomans and the Russian and Austrian empires. Certain local communities benefited from this shift in the diplomatic balance of power, especially Greek and other Balkan merchants who already participated in a thriving trade with central Europe. ${ }^{5}$ Alongside an Ottoman bureaucratic bourgeoisie, a commercial bourgeoisie materialized as Ottoman minority merchants engaged in trade with the West under the legal protection of major western powers. ${ }^{6}$ The gradual rise in the mercantile and shipping activity of the Ottoman Greeks reached its apogee between 1780 and 1820 , as non-Muslim Ottoman merchants acquired economic and social privileges which allowed them more freedom in their social behaviour, as demonstrated especially in their attire and their consumption of foodstuffs. ${ }^{7}$ Greek merchants played the all-important intermediary role between European powers and the Ottoman world which resulted in substantial financial prosperity for themselves and enabled their incorporation into the wider system of division of labour. ${ }^{8}$

Until recently, these significant developments have been neglected or ignored in Greek historiography, which bypassed the "dark age" of subjection to Ottoman rule under the telling term of Tourkokratia (Toupxoxpazia) Turkish rule). In many cases, Greek national (and nationalist) historiography has employed this non-historical dark age of undifferentiated and opaque Tourkokratia to transform the Greek presence under Ottoman rule into a discourse of proto-national victimization and martyrology. ${ }^{9}$ Such dominant onesided views have been exploited in different ways in the young Greek State of the 19th century and beyond: they were used as tools for nation-building, for shaping a collective identity, and for creating a more attractive national history, indeed a national mythology. This situation is gradually changing, leading to a more complex and nuanced understanding of the state of the Greek minority

5 Edhem Eldem, "Capitulations and Western Trade", in Suraiya N. Faroqhi (ed.), The Cambridge History of Turkey, Volume 3: The Later Ottoman Empire, 1603-1839 (Cambridge: 2008), 323.

6 Fatma Müge Göçek, Rise of the Bourgeoisie, Demise of the Empire: Ottoman Westernization and Social Change (New York: 1996), 44-45.

7 Sophia Laiou, "The Ottoman Greek 'Merchants of Europe' at the beginning of the 19th Century", in Evangelia Balta, Georgios Salakidis, Theoharis Stavrides (eds.), Festschrift in Honor of Ioannis P. Theocharides. Studies on the Ottoman Empire and Turkey, vol. II (Istanbul: 2014), 313-331.

8 Maximos, 49 .

9 Edhem Eldem, "Greece and the Greeks in Ottoman History and Turkish Historiography", The Historical Review, vol. 6 (2009), 33 and 37. 
in the Ottoman Empire. ${ }^{10}$ Although the Greek populations were certainly in a subservient position, that of a raya, experiencing great insecurity and being deprived of basic rights, we may challenge their position as victims and point to the need to discover and describe the specifics of their condition. Recent research suggests that the Ottoman system of power was not complacent at all, but at the same time it was not founded on direct and continuous violence. It was relatively stable, its stability resulting from the consent of its subjects. This consent did not reflect an ideal co-existence of different cultures but the structure of power relations and the imposition of power and violence, when necessary. ${ }^{11}$ Additionally, the social and intellectual stagnation did not necessarily mean material deprivation. ${ }^{12}$

Thus, despite the restrictive and highly regulated environment, the gradual decline of Ottoman rule and the aforementioned political developments in the second half of the 18th century led to an expansion of trade and brought about economic and cultural growth in the south Balkan area. The prosperity resulting from increased trade activities went hand in hand with and underpinned the emergence of a Greek bourgeois class, particularly on the centralnorthern mainland, the Aegean islands, and the cities of Constantinople (Istanbul) and Smyrna (Izmir), where the major hubs of commercial activities were to be found. Commerce on land and sea led to education, new professions, the establishment of technical guilds, and other bourgeois activities..$^{13}$ These, in turn, became the springboards for the differentiation of Greek bourgeois social strata, a distinct Greek "European" world within Ottoman society. ${ }^{14}$ The economic power of this rising Greek bourgeoisie was combined with deepening ties with Europe, with intellectual growth, and with the strengthening of a distinct identity. ${ }^{15}$ Among the expressions of this new identity was the acquisition and enjoyment of material wealth, including luxury objects. ${ }^{16}$

Within this context, Vassilis Panagiotopoulos discusses this transitional period for Greek communities under Ottoman domination at the end of the 18th century and the beginning of the 19th. He writes about new attitudes that

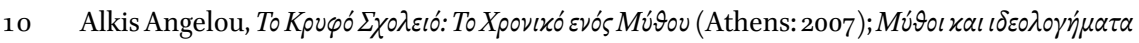

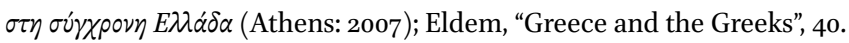

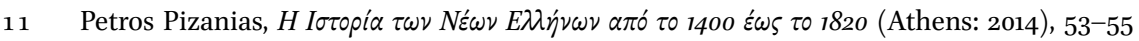
and 99.

12 Pizanias, 132.

13 Pizanias, 422.

14 Pizanias, 431.

15 Pizanias, $45^{8 .}$

16 Göçek, Rise of the Bourgeoisie.
} 
emerge at the turn of the century in "the city of Enlightenment, Yannina", especially as far as women are concerned. There were numerous signs of a new ethos in town: new sartorial habits accompany more liberal morals and novel behaviours. This ethos became more and more visible to Christians and Muslims alike, even threatening, as it upset longstanding beliefs and habits as well as questioned the status quo. There was a faint, albeit real, echo of new messages that emanated primarily from the cities of the European Enlightenment and reached Yannina via the local Diaspora. Influences from Paris, Vienna, various Italian cities, Budapest, the Danubian Principalities, as well as Istanbul, were corroding the traditional local nexus and set the tone for the approaching change. ${ }^{17}$ Fashion was included in the public expression of an emergent bourgeois identity. Although Ottoman sumptuary laws restricted the use of specific fabrics or colours, and interventions by ecclesiastical authorities condemned luxury as a moral sin, the invasion of novelty was forceful and women participated in these transformative processes. ${ }^{18}$

\section{Greek Bourgeois Women: Sources and Images}

This chapter deals with Greek-speaking Christian women belonging to the Rum millet of the Ottoman Empire; constrained by both gender and religion, they occupied a sensitive position in the social milieu, where established conventions placed "men above women and Muslims above non-Muslims". ${ }^{19}$ The chapter focuses, in particular, on the lives of women of the emerging Greek middle class. ${ }^{20}$ The time frame of the study is the long 18 th century, i.e., up to the beginning of the Greek War of Independence in 1821. This period may be described as a significant transitional phase: in political and social terms, it prepared the demand for autonomy and eventually the War of Independence. ${ }^{21}$ These developments arguably influenced women in ways that are not fully documented and therefore require extensive research.

More generally, the position and role of women living in the Ottoman Empire is a topic neglected by academic research. Madeline Zilfi notes that

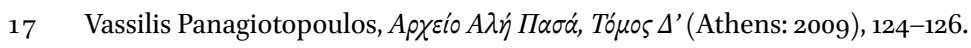

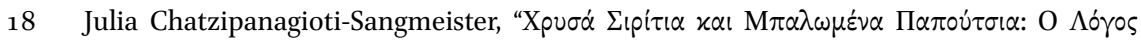

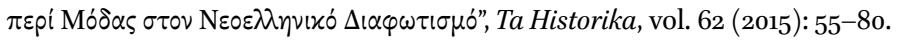

19 Betül İpşirli Argit, "Women in the Early Modern Ottoman World: A Bibliographical Essay", Akademik Araştilmalar Dergisi 60 (2014): 7.

20 Greek women of the urban poor or rural populations are not discussed in this chapter.

21 Pizanias, $455^{-476 .}$
} 
historians of the Ottoman era, with few exceptions, have not "attended to women", although she acknowledges that, as of the mid-1980s, thanks to the historiographical turn towards social historical themes, the study of women and gender began to assume a more central place in the new history "from below", especially through research into state archives, court records, and travel accounts. ${ }^{22}$ Edhem Eldem observes, in particular, the "much understudied world of men and women of modest means, the urban poor, the rural populations and the marginal characters of port cities". ${ }^{23}$ Betül İpşirli Argit also states that more image-based studies are needed for non-Muslim women, to complement the studies based on written sources. ${ }^{24}$ Despite the progress thus far, the world of Greek women in the Ottoman Empire remains largely unknown, making it very difficult to imagine or reconstruct this world through concrete examples. With few exceptions, such as studies preserving the names of specific women, resources on this topic are scarce and the female world remains largely hidden from us. ${ }^{25} \mathrm{~A}$ recent research programme $(\mathrm{O}$ Hermēs ton Neon Ellennon 1700-1832) involved the creation of a digital database of personal data for Greek people in the Early Modern period, including information on 37,183 individuals, all men, among them 4,287 revolution fighters, 1,532 members of the Filiki Etaireia secret society, and 483 intellectuals. ${ }^{26}$ Given the scarcity of information on women, this repository of distinguished men is arguably a precious source for approaching female lives indirectly, in the same way that the correspondence between two Greek brothers about marriage offers valuable insights into the position and habits of Greek women in the first half of the 18th century. ${ }^{27}$

Foreign travellers' accounts are also sources of substantial value, offering a combination of textual and visual material which, however, should be treated with great caution. While printed visual sources by foreign travellers constitute a charming and legible corpus bearing a multitude of signs about

\footnotetext{
22 Madeline C. Zilfi, (ed.), Women in the Ottoman Empire: Middle Eastern Women in the Early Modern Era (Leiden: 1997).

23 Eldem, "Greece and the Greeks", 32.

24 Betül İpşirli Argit, "Visual Material as a Source for the Study of Ottoman Women in the Early Modern Era", in: Türe, D. Fatma and Birsen Talay Keşoğlu (eds). Women's Memory: The Problem of Sources (Newcastle upon Tyne: 2011), 29-39.

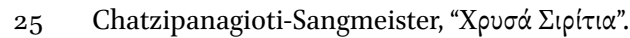

26 Pizanias, 229, 410 and 415 .

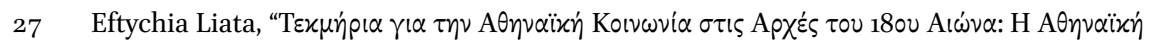

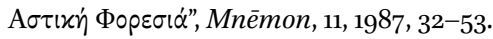


history, sociology, and fashion, they are a research tool that should be used with prudence. ${ }^{28}$ For instance, Olga Augustinos rightly observes that "Useful though they may be as sources of information, travelogues are even more significant as documents showing the reasoning process, criteria, and perceptual framework that representatives of one culture, in this case western European, used consciously or unconsciously in order to understand and evaluate another culture."29 Admittedly, the representations of the "Other" in travellers' accounts constitute a repository of collective knowledge that also included stereotypes for the "Other".

The content of such accounts was often based on fleeting impressions, unchecked information, or personal idealizations. This filtering of experience and the ensuing process of conversion followed the standards and values of the viewer. Although popular collections of engravings attempt to record the typical, what is seen as typical is more often than not the alien-in other words what is divergent from the standards of the society from which the travellers and their public emanate. This leads to generalizations and results in the propagation of stereotypes for the "Other". At the same time, early modern European travel-writing offered valuable insights into otherwise undocumented realities, in this case into the lives of Christian women in pre-revolutionary Greece, especially since ethnographic interest assumed a more scientific and systematic character during the 18th century, leading travellers to switch their attention to daily life. ${ }^{30}$ Furthermore, travel accounts opened European minds to cultural diversity as they enabled the circulation of so many foreign elements. $^{31}$

\section{The Von Parish Library as a Research Resource}

In this context, a relevant resource has been identified: the von Parish Costume Library (von Parish Kostümbibliothek) in Munich, part of the city's municipal

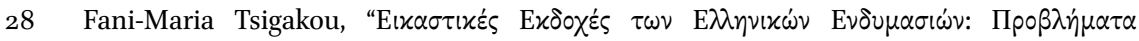

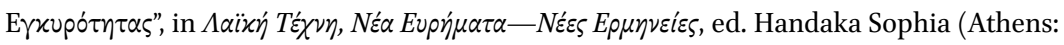
2015), 81-90.

29 Olga Augustinos, French Odysseys: Greece in French Travel Literature from the Renaissance to the Romantic Era (New York: 1994). See also: Ioli Vingopoulou, Travelogues, 2014, http:// eng.travelogues.gr, Aikaterini Laskaridis Foundation [accessed 30 May 2017].

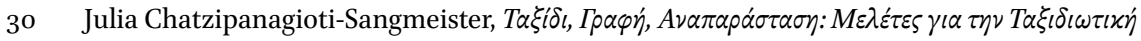

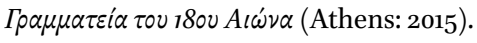

31 Alexander Bevilacqua and Helen Pfeifer, "Turquerie: Culture in Motion, 1650-1750", Past and Present, no 221 (2013), 89. 
museum (Münchner Stadtmuseum). Accessible yet unexplored, this resource has offered a useful point of departure for the study of Greek women in the Ottoman Empire.

The von Parish Costume Library is a large collection of more than 35,000 books, 50,000 drawings and prints, and 500,000 photographs. The collection was created by Hermine von Parish (1907-1998), who had a passion for female costume and gathered the material over several decades through her travels and her searches for items in antique shops and auction houses. In 1970, the collection was bought by the municipal museum of Munich and is now available to researchers for study. However, the library material is inadequately documented and there is minimal information about provenance or about the logic behind the collection. ${ }^{32}$ According to Dr. Esther Sünderhauf, director of the von Parish Costume Library, the only criterion for purchases was the subject of costume: Hermine von Parish was collecting visual material from any place and time, as long as it was a representation of costume and dress. Acquisitions, including individual prints and drawings, photographs, and newspaper cuttings, as well as books, were not recorded when the purchases were made. ${ }^{33}$ The cost of documentation and the lack of appropriate staff have further hindered subsequent procedures of cataloguing. ${ }^{34}$

Within the collection, items of direct relevance to Greek women of the 17th-19th centuries include a copy of the highly influential publication Trachten und Gebräuche der Neugriechen (Costumes and Customs of the New Greeks) published in 1831 by the classicist and traveller Otto Magnus von Stackelberg (1786-1837), ${ }^{35}$ as well as a number of individual prints on paper made using various techniques (lithographs, copperplates, woodcuts, etc.), either mounted on card or placed in passe-partouts. Several of the prints can be

32 Susanne Hermanski, "Schöne Hüllen gegen böse Geister", Süddeutsche Zeitung, 17 April 2007, 45; Jürgen Moises, "Dem Zeitgeist auf der Spur", Abendzeitung, 18 April 2007; Gabi Peters, "Wo der Modezar am Bananenrock schnüffelt", Bayerische Staatszeitung, no. 36, 7 September 2007; Stephan Handel, "Die Mode-Sammlerin”, Süddeutsche Zeitung, 14 April 2009; Erika Dichtl, "Ein Leben für die Geschichte der Kostüm-Mode: Hermine von Parish", Neuhauser Werkstatt-Nachrichten, November 2012, 58-62.

33 Personal communication by e-mail with Dr. Esther Sünderhauf, 15 December 2015.

34 Hermine von Parish, "Bibliothek und Dokumentation des Kostümforschungsinstituts von Parish in München”, Bayern BFB, vol. 18 (3) (München: 1990), 302-311. The catalogues of the library that have been consulted for the present text include the title of each item, its production technique (e.g. copperplate, coloured lithograph, etc.), and the value in German Marks (it is unclear if this was the price paid for the acquisition of the item or an estimated value at the time of the catalogue creation).

Otto Magnus von Stackelberg, Trachten und Gebräuche der Neugriechen, (Berlin: 1831). 
identified as copies of images from well-known travelogues: Joseph Pitton de Tournefort's (1656-1708) travel account with illustrations by the artist Claude Aubriet (1665-1742), ${ }^{36}$ the travel account of Choiseul-Gouffier (1752-1817) with images by the artist Jean-Baptiste Hilaire $\left(1753^{-1822)},{ }^{37}\right.$ as well as the aforementioned von Stackelberg publication. Arguably, the earliest representation of a Greek woman in the collection is the print entitled "Concubina Rhodiana" (Catalogue Number Pa/12808), a copy of an image from the late 17th-century travelogue of Rhodes Island by Vincenzo Maria Coronelli (1650-1718). ${ }^{38}$ There are also various copies of prints by Christoph Weigel the Elder (1654-1725), who was active in Nuremberg. In Early Modern Europe, prints reproducing images from travelogues were very popular and were widely copied, reproduced, and circulated; indeed, they became highly desired objects of consumption. Among other things, prints satisfied the public appetite for impressions and knowledge of other cultures; the distinctive characteristics of prints as commodities may also reveal a lot about the rise of interest in superfluous objects in general. ${ }^{39}$ Printed engravings of foreign cultures were luxuries the middle classes of Europe could afford and they were inseparable from new forms of economic and commercial organization. ${ }^{40}$

The use of images as historical evidence is a relatively new endeavour and enables historians of the present to "imagine" the past more vividly. ${ }^{41}$ Images may operate in a complementary fashion to written documents, as they help visualize information that has been mentioned in written texts or provide evidence for aspects of social reality that the texts have overlooked. Visual material offers clues about small details and enables us to get a feel of the spirit of

36 Joseph Pitton de Tournefort, Relation d'un Voyage du Levant, fait par ordre du Roy. Contenant l'histoire ancienne \& moderne de plusieurs Isles de l'Archipel, de Constantinople, des côtes de la Mer Noire, de l'Armenie, de la Georgie, des frontières de Perse \& de l'Asie Mineure. Avec les plans des villes \& des lieux considérables ..., t. I, (Paris: 1717).

37 Marie-Gabriel-Florent-Auguste de Choiseul-Gouffier, Voyage Pittoresque de la Grèce (Paris: 1782).

38 Vincenzo Maria Coronelli and Antonio Parissoti, Isola di Rodi Geografica-Storica, Antica e Moderna, coll' altre adiacenti già possedute da Cavalieri Hospitalieri di S. Giovanni di Gerusalemme. Opera de Padri Maestri Coronelli Cosmografo della Serenissima Republica di Venetia, e Parisotti Storiografo dell' Accademia Cosmografica degli Argonauti ..., (Venice: 1688).

39 Peter Parshall, "Prints as Objects of Consumption in Early Modern Europe", in: Journal of Medieval and Early Modern Studies, vol. 28, (1998), 19-36.

40 Bevilacqua and Pfeifer, 79.

41 Peter Burke, Eyewitnessing: The Uses of Images as Historical Evidence (London: 2001). 
the age. ${ }^{42}$ Such "glimpses of lived lives" 43 support our efforts to reimagine the lives of Greek women in the Ottoman Empire. Even though the von Parish collection is a modest resource, shaped by the sincere passion of its creator and not by the systematic and scientific mentality of a researcher, the collection offers the latter direct access to original visual material from the past and may contribute to informing new research. Given these reservations, the images from the von Parish collection deserve to be examined in conjunction with and complementary to other sources.

\section{From Images to Objects}

Three copperplates have particularly attracted our attention because of the richness and originality of their content. They are entitled "Bourgeoises de l'Ile de Tine" (Bourgeois Women of the Island of Tinos) (Catalogue Number

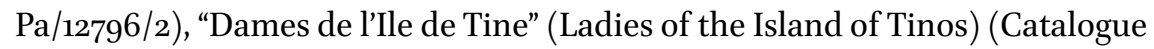
Number Pa/12796/1), "Femmes de l'Ile de Santorin" (Women of the Island of Santorini) (Catalogue Number $\mathrm{Pa} / 12848$ ) respectively, and can be identified as copies of the original illustrations with the same titles made by Jean-Baptiste Hilaire and included in the account of the 1776 travel of Marie-Gabriel-FlorentAuguste de Choiseul-Gouffier, published in Paris in 1782 under the title Voyage Pittoresque de la Grèce. ${ }^{44}$ In the reproductions found in the von Parish collection, the drawings are mirrored and of lower quality than the originals by Hilaire, lacking in precision and clarity. A more thorough examination of the details of objects depicted in the images would entail viewing images from the original Choiseul-Gouffier publication. Despite the low quality of the images examined, their content is fascinating and shows rare views of interior spaces of Greek households in the Ottoman Empire, including images of women and children.

The image entitled "Bourgeoises de l'Ile de Tine" shows a woman with her two children in a room, sitting next to a window with a drawn curtain on a sofa richly covered with textiles. The woman is apparently teaching the elder child how to knit, while the younger one may be seen in a wooden cot nearby. Both mother and elder child wear elegant clothes and elaborate headdresses;

42 İpşirli Argit, "Visual Material", 29-39. İpşirli Argit, "Women in the Early Modern Ottoman World".

43 Zilfi, Women in the Ottoman Empire, 5.

44 Choiseul-Gouffier, Voyage Pittoresque de la Grèce. See also Christine Peltre, Retour en Arcadie: Le Voyage des Artistes Français en Grèce au XIXe Siècle (Paris: 1997). 
the woman also wears a pendant necklace. On the wall behind them, there is a shelf with various ceramic vessels (bowls, jugs, etc.), while on the side there is a window with a plush curtain. Overall, the image gives not only an impression of material ease, but also, and more importantly, an atmosphere of peace and dignity, where the mother enjoys time spent with her children, looking after them and teaching them.

In another mirrored copy of an Hilaire image from the Choiseul-Gouffier publication, the illustration entitled "Dames de l'Ile de Tine", two elegantlydressed, young-looking women sit by a window, one of them holding a book and reading, the other one sitting in a very leisurely manner, either listening or daydreaming, with a cat by her side. On one side of the women, there is a wooden table with some vessels (lamp, ceramic plates, jug, and bowl with spoon), on the other side there is a musical instrument (a version of tambouras) on the couch. The image is extraordinary in that it associates women with two activities, reading and music-playing, which may be considered as elements of a highly cultivated, comfortable, even sumptuous life.

The third illustration, entitled "Femmes de l'Ile de Santorin", shows two women relaxing and conversing in an interior space, by the window. The image of the space surrounding them is punctuated by several objects indicating a comfortable existence: the furniture is covered with rich textiles, wine containers may be seen on the floor and various ceramic vessels on a shelf. Behind the women there is a large mirror with a wooden frame and a wooden carved desk with rolled-up documents on top of it. The women's posture and the general ambience created by the various objects suggest an enjoyable lifestyle, as well as a society in contact with foreign lands, from where some of these objects perhaps originate.

The publication by Choiseul-Gouffier corresponded to and reinforced the cultural and artistic norms of his time and of his privileged cultural milieu; he offered an entry point to an idealized Greek antiquity as well as a quasiethnographic take on the activities of contemporary women. ${ }^{45}$ His work paid attention to both ancient and modern architecture and customs. ${ }^{46}$ The artist Hilaire transposed into these images the sensitivities or preoccupations of Choiseul-Gouffier who commissioned them and who used the word "picturesque" in the title of this publication. Even though Choiseul-Gouffier claimed his reproductions to be faithful, the possibility that they were somewhat idealized should certainly be taken into account. How true could the languid poses 
of women reading and the sophisticated interiors be during a time when islands such as Tinos were known for their rusticity? ${ }^{47}$ On the other hand, in the course of the 18th century, Tinos was a dynamic maritime commercial hub. The island experienced a relatively brief Ottoman domination (after 1715) and, having previously been under Venetian domination, retained strong links with Italy. Tinos had an important intermediary role in the trade between Izmir, the Aegean archipelago, and Italian ports, especially as far as the cloth trade was concerned. It also produced silk and silk handicrafts such as purses, gloves, and stockings for export, although relevant information remains limited. ${ }^{48}$ Similarly, other Aegean islands participated actively, via Izmir, in the wider European market. ${ }^{49}$

Another group of prints in the von Parish collection consists of copies of images from the von Stackelberg publication. ${ }^{50}$ Many of these images became very popular and were reprinted numerous times, illustrating other travellers' accounts too. Von Stackelberg's paintings of folk themes are impressive; the subjects, as well as the posture and movement of the figures, are quite novel and diverge from the established models of the period. ${ }^{51}$ One of the images shows a beautifully-dressed young girl from the island of Kasos sitting on a large pillow on the floor and making her braids; the image exudes a carefree but melancholic atmosphere. ${ }^{52}$ Another image shows an elaborately-dressed woman from Missolonghi (mainland western Greece) standing and lighting a lamp. ${ }^{53}$ On a separate sheet of unknown origin (Catalogue Number Papr/648/84) the two previous images are combined in one. The existence of this double image might imply that these illustrations had made an impression and variations of them were reproduced commercially. The quality of the combined drawing is lower than in the original and the colours are slightly different. One detail is, however, worth mentioning: although in the original drawing of the Kasos girl there is a small comb on the floor next to her as she sits, in the copy the comb has been replaced by a book. The change is hardly discernible, due to the small size of this detail and the similarity of the object shapes; it is however a poignant one. What does it signify? Why did the artist take this liberty? Was

\footnotetext{
47 Peltre, $28-31$.

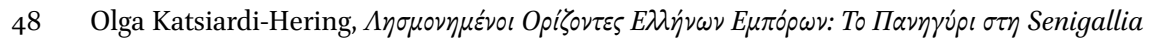

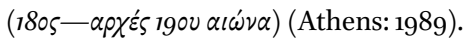

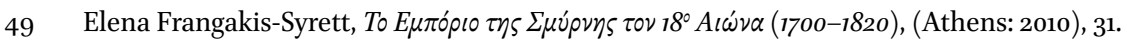

5o Von Stackelberg.

$5^{1}$ Vingopoulou.

$5^{2}$ von Stackelberg, Xxvi.

53 von Stackelberg, $\mathrm{xxx}$.
} 
it reflecting the reality of a girl who was not only elegant but also educated? More importantly, was it just the copier's idea to make the illustration intriguing to the projected audience? While it is impossible to answer these questions with certainty, they are indeed thought-provoking; the next section is dedicated to the significance of such objects.

\section{Focusing on Objects}

Museums, libraries and private collections include items similar to those portrayed in the images described in the previous paragraphs. By comparing actual objects found in museums to those shown in images and by seeking relevant texts to document and complement them, we introduce the idea of materiality to our analysis of middle-class women. As Sophia Handaka notes, it is desirable to materialize in a metaphorical sense the period under discussion and to reconstruct it with objects at its centre. ${ }^{54}$ Handaka emphasizes, in particular, secular arts and crafts of pre-revolutionary Greece (early 18th to 19th centuries), including wood carving, stone carving, pottery, wares of silver and gold, metalwork, jewellery, embroidery, weaving, textiles and dress. In this vein, we attempt to bring to life some of the objects illustrated in the aforementioned images by identifying specific items from contemporary museum collections, such as belt buckles, combs, mirrors, chests, musical instruments and books.

To begin with, the reading woman in "Dames de l'Ile de Tine" is dressed very elegantly, with a long fur over her shoulders, which falls to the floor, and a belt with a buckle made of two circular or elliptical elements on her lap. The belt buckle was one of the most widespread accessories of female attire in the period under consideration. Worn not around the waist, but around the hips, as fashion dictated towards the end of the 18th century, the low belt, or hip belt, was usually an expensive object with valuable silver or gilded buckles, often a masterpiece of workmanship. ${ }^{55}$ The belts with their elaborate buckles were not only vehicles for showing off personal wealth and status, but also a form of

54 Sophia Handaka, "The Objectification of History and the Historicizing of Objects: Understanding Neo-Hellenic Secular Art and Material Culture", in Paschalis M. Kitromilides and Dimitris Arvanitakis, eds. The Greek World Under Ottoman and Western Domination 15th19th centuries (New York, 2008), 93 .

55 Podoabe Din Trecut, Colecţia de Paftale a Muzeului Naţional de Artă al României (Bucharest: 2015). 
portable investment that was easy to carry in case of emergency. ${ }^{56}$ Thanks to their durable material, numerous belt buckles made with great craftsmanship into intricate designs are preserved these days in private and public collections all over the Balkans; however, research on the topic has been limited. For instance, the buckle in the aforementioned image resembles a silver buckle from the National Museum of Art of Romania, Bucharest (Inventory number 14512/ $P$ 462). It is made of wrought silver with chiseled border floral decoration and baroque influences; the centre of the rounded buckle part bears a basket from which flow leaves and flowers, often considered symbols of plentifulness and fertility. The object must have belonged to a Greek family, as indicated by the name inscribed on the back side of the buckle. ${ }^{57}$

The collection of the National Historical Museum in Athens includes a set of combs (Inventory Numbers 533 and 534 respectively) similar to the comb portrayed in the von Stackelberg image of the girl from Kasos. The set is of Chinese origin, possibly from the end of the 18th century or the beginning of the 19th, and was donated to the museum by a private collector sometime between 1882 and $1891 .{ }^{58}$ The combs are made of wood, incorporating bone and ivory details as well as painted floral decorations and inscriptions in Chinese. They are very delicate and elegant objects; their obvious link to female beauty care suggests a lifestyle that was clearly elevated beyond mundane concerns of survival. Ongoing research on the painted decoration and inscription is expected to reveal more information about the provenance and significance of these items. Although more data is needed to assess their value, their status as items imported from a very distant place suggests that they were objects of distinction. Additionally, the fact that these very fragile items have been preserved to this day might be an indication that they were valuable, treasured, and kept in a safe place.

Similar to combs, mirrors are items directly related to beautification, as well as to the importance of one's self-image; they are therefore symbols of vanity,

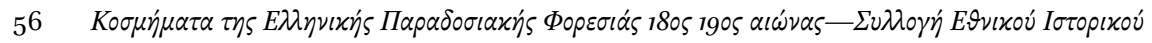

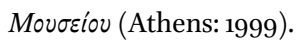

57 Podoabe Din Trecut, 42.

58 The documentation of the museum on these combs suggests that they were used by an Athenian lady in the late 17th century. However, this may have been an exaggeration by Alexandros N. Meletopoulos (1855-1927), the collector who donated them. Following discussions with curators from the National Historical Museum in Athens and from the anthropological Museum Fünf Kontinente in Munich, as well as online searches of similar items in museums worldwide, late 18th or even early 19th century seems a more plausible date. 
of which Christian morality disapproves. ${ }^{59}$ Early mirrors were rather primitive, made of metal which was then so highly polished that one could see one's face in it; the modern, silver mirror did not come into use until around the 16th century. ${ }^{60}$ For most of its history, the metal-backed glass mirror has been regarded as a luxury. ${ }^{61}$ Venice, the major hub of glass production worldwide, was the primary source of mirrors in the 18th century, although towards the end of the century Venetian glass products were supplanted by German glassware, especially from Bohemia. Despite the political and commercial decline of Venice in the 18th century, her trade to the East still retained a strong standing. Luxury products from Venice, including glass vessels and mirrors, were popular among Turks, Greeks, and other inhabitants of the East and saved the Venetian trade from total collapse. ${ }^{62}$ It has been argued that the "mirror culture" of the East was very conservative and underdeveloped, therefore most mirrors were imports from the West. ${ }^{63}$ Mirrors were valuable objects that held a special role in households and they were also often used as gifts or bribes to dignitaries. In 18th century Greece, the mirror had the aura of a beautiful, precious, and "modern" imported product, which served as a symbol of wealth and social prestige. Furthermore, the mirror was considered to be a technological, "industrial" product, because artisans in the Ottoman Empire did not possess the materials or know-how for the production of high-quality mirrors. ${ }^{64}$ Small mirrors were also often incorporated into the underside of chest lids made for special uses. ${ }^{65}$

Chests themselves had twofold connections to luxury: on the one hand, they were beautiful, handcrafted items, on the other hand, they were intended to store dowry items and other precious things such as documents and jewellery that were only used on special occasions and had to be protected. ${ }^{66}$ Furthermore, in medieval and modern culture, the chest was dually coded

59 Gustav Friedrich Hartlaub, Zauber des Spiegels: Geschichte und Bedeutung des Spiegels in

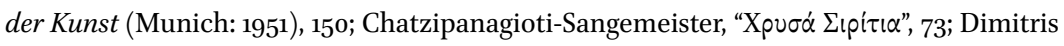

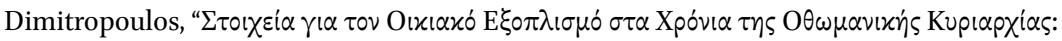

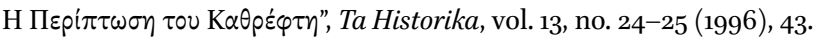

6o Neil MacGregor, A History of the World in 100 Objects (London: 2012), 318.

61 Barbara Maria Stafford and Frances Terpak, Devices of Wonder: From the World in a Box to Images on a Screen (Los Angeles: 2001), 256.

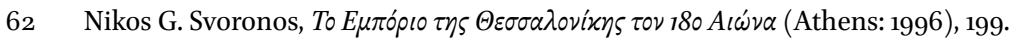

63 Hartlaub, 58-59.

64 Dimitropoulos.

65 Virginia Matseli and Aris Tsaravopoylos, $H E{ }^{2} \lambda \eta \nu\llcorner\varkappa \dot{~ K \alpha \sigma \varepsilon ́ \lambda \alpha ~(A t h e n s: ~ 2010), ~ 50-51 . ~}$

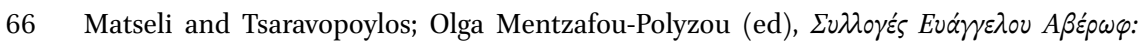

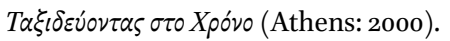


as the object which stored a person's most valuable possessions as well as enabling them to remain mobile. ${ }^{67} \mathrm{~A}$ fine example of a wood-carved chest with a mirror incorporated into the underside of the lid is kept in the Averoff Collection, Metsovo (Catalogue Number $\Gamma E_{-} 538$ ); two other elaborately carved and decorated chests may be seen at the Benaki Museum, Athens (Catalogue Numbers $\Gamma E 12935$ and $\Gamma E 8719$ ). The von Parish images also include representations of various other items of furniture which, whether locally produced or imported, express changing habits in the use of space. Chairs, high tables, high sofas and chests of drawers exemplify a shift from the typically low and cushioned Ottoman seating towards a more European use of space. ${ }^{68}$

The musical instrument shown in "Dames de l'Ile de Tine" sets new challenges for research. The object may be identified as a stringed, pear-shaped tambouras, a member of the lute family that was widely used in pre-revolutionary Greece. The neck of such an instrument would typically be straight, but there were also cases of a slanted neck, similar to that of a lute, as is the case of the tambouras shown in this image. ${ }^{69}$ The tambouras was usually played without the support of other instruments and produced a "thin" and relatively weak sound that was particularly appropriate for accompanying singing or dancing by a small group. Consequently, tambouras music playing was more fitting to interior spaces; ${ }^{70}$ it would therefore suit women who were for the most part living in their private quarters. The identification of a musical instrument as an object used by women during their leisure time suggests

67 Folklorist Konrad Köstlin quoted in Alexander Klose, The Container Principle: How a Box Changes the Way We Think (Cambridge MA: 2015), 148.

68 A reverse trend may be observed in the phenomenon of Turquerie, the pan-European interest in and emulation of Ottoman culture between $165^{\circ}$ and $175^{\circ}$ (Bevilacqua and Pfeifer, 75). Luxurious furniture for leisure, informal and liberating but luxurious dress closely associated with Ottoman attire, and "oriental" decorative elements were manifestations of highly complex, mutual cultural exchanges between Europe and the Ottoman Empire (Bevilacqua and Pfeifer, 93 and 103-104).

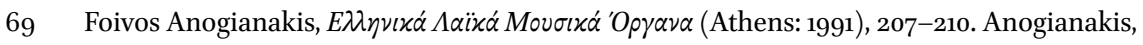
a respected authority on the history of Greek musical instruments, doesn't provide any information on his sources about different tambouras typologies. Our research into museum collections, in the MIMо database for musical instruments: Musical Instruments Museum Online, http://www.mimo-international.com/MIMO/ [accessed 30 May 2017], as well as contact with private collectors have indicated that no instruments of this type and time period have survived. This is also suggested in "Ottoman Music and its Instruments", http://www.turkishculture.org/music/classical/ottoman-music-instruments-282.htm? type $=1$ [accessed 30 May 2017]. 
a cultivated background and a privileged existence. Although there are various representations of and references to this instrument in accounts by western travellers, it is difficult to say to what extent such accounts have been influenced by the orientalist clichés that existed to satisfy the demands of the intended clientèle. ${ }^{71}$ Since no surviving instruments from that period have been identified, the best approximation to the tambouras under discussion would be the one owned and used during a later period by the Greek revolutionary fighter Yannis Makriyannis (1797-1864). This instrument, kept at the National Historical Museum in Athens (Inventory No 3729), was created in the 1820 s to replace Makriyannis's pre-revolutionary instrument that had been destroyed..$^{72}$

The woman reading in the image "Dames de l'Ile de Tine" also attracts our attention: she seems to be enjoying a book, perhaps reading aloud to her companion. Greek books in the 18th century were produced outside the main territory of Hellenism, for example in Venice or Vienna. Typical ways in which they could be acquired were in person at large regional fairs in Greece, during travels abroad, or ordered through a subscription-based system. ${ }^{73}$ The great bulk of Greek publishing during the Ottoman rule consisted of books of religious content; there were also grammars and miscellaneous publications with secular content, but at the end of the 18th century books of religious content still outnumbered those with secular content. ${ }^{74}$ In any case, a mere seven percent of books published by subscription for a Greek readership between 1749 and 1832 were ordered by subscribers in areas (like Tinos) that would belong to the independent Greek state after the revolution; the majority were ordered by the Greek Diaspora of central and western Europe, France, Italy and Russia. ${ }^{75}$ We can only speculate about the type of the book that the woman in the picture was reading. Could it be a copy of Erotokritos, the romantic poem written

71 Christina Ghirardini, "'Eyewitness' Accounts of Turkish Music and Dance in the Eighteenth Century", Imago Musicae xxvi (2013), 47-77. See also: Cem Behar, "The Ottoman Musical Tradition”, in Suraiya N. Faroqhi (ed.), The Cambridge History of Turkey, Volume 3: The Later Ottoman Empire, 1603-1839 (Cambridge: 2008), 393-407.

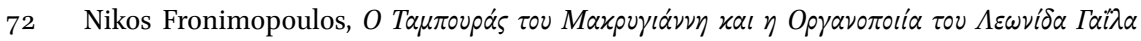
(Athens: 2010).

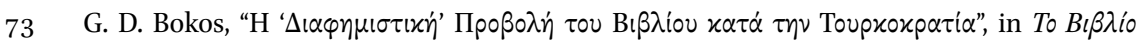

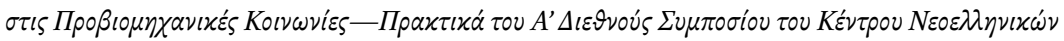

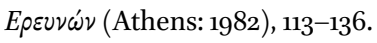

74 Richard Clogg, "Elite and Popular Culture in Greece under Turkish Rule", Indiana Social Studies Quarterly, vol. 32, 1979, 69-88.

75 Richard Clogg, "The Greek millet in the Ottoman Empire", in Christians and Jews in the Ottoman Empire: The Functioning of a Plural Society I, The Central Lands, eds. Benjamin Braude and Bernard Lewis (New York: 1982), 185-207. 
by Vitsentzos Kornaros in the early 17 th century and subsequently widely published and read? ${ }^{76}$ A copy of Erotokritos, published in Venice in 1804, may be seen today at the Bavarian State Library (Bayerische Staatsbibliothek) in Munich (BSB-ID: 852361). This highly popular "erotic" book was condemned by religious circles as "heretic" and its use was described as a "sin". ${ }^{77}$ Given these conditions, a female reader on the island is definitely a case deserving further attention.

\section{Evidence from Written Sources}

All in all, these images suggest that the private world of these women, although sheltered, was at the same time open to a variety of influences and ideas; the material objects that populated their world were instrumental in the circulation of such influences and ideas. Written sources such as correspondence, probate inventories, archives of court cases, ecclesiastical archives and literature may offer valuable supporting evidence on the role of such objects in the lives of women. ${ }^{78}$ Three selected examples of written sources are presented in the following paragraphs.

The first one consists of the correspondence, in 1787 , between two female members of the Greek elites, in Istanbul and Iaşi respectively, about fash-

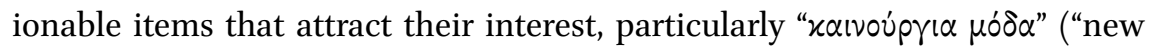
fashion"), which is presumed to be the first ever mention of the term "fashion" in the Greek context. The study of this correspondence opens a window to the world of women in the higher strata of Greek society within the Ottoman Empire. Although female members of this social circle were restricted to the private sphere and to a limited range of experiences, the specific epistolary

${ }_{76}$ Gavin Betts, Stathis Gauntlett and Thanasis Spilias, Vitsentzos Kornaros, Erotokritos: A Translation with Introduction and Notes (Melbourne: 2004), xxvii.

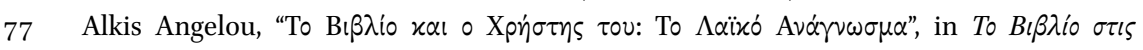

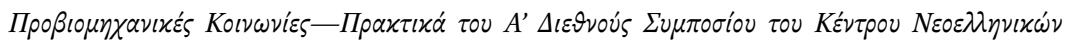

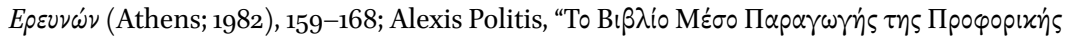

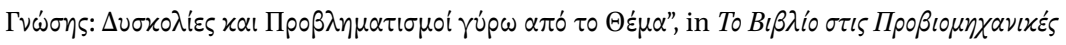

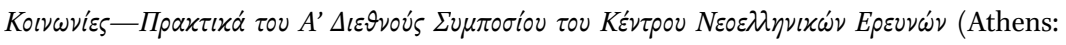
1982), 271-282.

78 Ad Van Der Woude and Anton Schuurman, Probate Inventories: A New Source for the Historical Study of Wealth, Material Culture and Agricultural Development (Wageningen: 1980). 
exchange reveals an awareness of new ideas by these women and their active involvement in new trends related to dress. ${ }^{79}$

This new awareness was arguably permeating the middle classes too, as reflected in the second source, a letter from the archive of Ali Pasha, the notorious ruler of Yannina, in the Epirus region of mainland Greece. The letter, dated 18 September 1800 (Gennadius Library Athens, Ali Pasha Archive, no 587), is addressed by a Greek mother, writing (in Greek) from an unidentified location, to her son in Istanbul; she sends him wishes and greetings and scolds him for not writing more often. The names mentioned in the letter and the language used suggest a connection to the Aegean islands. Although it is unclear why this letter was included in the archive of Ali Pasha, it is assumed that there must have been an indirect connection between him and the people related to the letter. ${ }^{80}$ The following request attracts our attention to this otherwise ordinary communication between a mother and her son: "do send me a çevre for spalleto for the winter and take care of dyeing the silks". Here, the Turkish çevre refers to a piece of embroidered handiwork that she needs to use as a spalleto, which in Italian means a type of knitted or woven shawl for the shoulders. This fascinating detail suggests an awareness of special products that were not available in the direct vicinity of the woman's place of residence, as well as a desire to acquire them. The reference to the silks that need to be dyed, although unclear and out of context, also indicates an interest in special or even luxurious items. Additionally, the free-flowing handwriting and the language used reveal an educated and self-assured woman. ${ }^{81}$

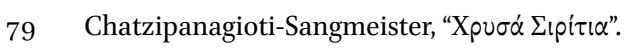

8o Panagiotopoulos, 113-114.

81 It is worth noting the amount of information that can be extracted from the actual physical object (as opposed to a mere transcript of the text), which demonstrates the value of hands-on, object-based research. Apart from the examination of the handwriting, the viewing and handling of the paper itself offers valuable information. In the 18th century, the majority of paper was imported to the East from Venice and Genoa; smaller quantities of high-price paper were imported from France (Svoronos, 267). Originally, all European paper was hand-made by dipping a wooden-framed metal screen (a mould) into a vat of warm water and cellulose fibres (made from disintegrated rags). Until the late 18th century, all moulds had the same basic design: a rectangle with widely-spaced vertical wooden ribs, a "chain" wire laced to the top of each rib, and closely-spaced horizontal "laid" wires tied to the chains. Wire designs sewn to this grid, when used, formed decorative and informative watermarks. "Laid" paper was thinner where the pulp touched the wires, making a latticework pattern easily seen when held up against light. Erin Blake, "Learning to 'Read' Old Paper”, http://collation.folger.edu/2012/o6/learning-to-read-old-paper/ [accessed 
These examples may be seen as an indication that Greek women, restricted by sumptuary laws and other social limitations, had developed distinctive consumer attitudes which did not go unnoticed, as the third example shows. The Turkish poet Enderûnlu Fâzll (1757-1810), in his popular poem Zenân-Nâme (The Book of Women), composed at the end of the 18th century and published posthumously, describes the habits of Istanbul women of various ethnic backgrounds. He dedicates a large section of his poem to Greek women, extolling their virtues and idealizing their beauty and intelligence. According to Scottish orientalist Elias John Wilkinson Gibb (1857-1901), Fâzil was a representative of Turkish Romanticism and his work was a revolt against traditional authority, an assertion of individuality, and an unbridled licence alike in matter and manner. Fâzl's book was banned, which suggests that its content was considered provocative and incompatible with mainstream views on women. ${ }^{82}$ Among other things, when writing about Greek women, he notes: "Yon diamond aigrette awry she wears"! 83 The diamond aigrette, a luxury fashion accessory, is worn "awry" by Greek women, in other words, in an unusual, non-conventional manner. We may read between the lines a metaphor for the behaviour of Greek women in general. This small detail, the use of a headdress accessory, may signify the woman's desire to express her individuality and digress from the established norms and restrictions imposed upon her; the aigrette is an item offering possibilities of self-expression. ${ }^{84}$ The impression rendered by the above verse may be linked to the portrait of a Greek bourgeois lady from the Fener district of Constantinople, an 18th-century oil painting

30 May 2017]. The sheet on which this letter was written is "laid" paper, typical of the 18th century. In addition to the latticework pattern, a watermark in the form of a crudely outlined bird may also be discerned on the paper sheet. It has not been possible to identify this specific design in LIMA: Watermark Databases, http://www2.warwick.ac.uk/fac/ arts/ren/projects/lima/paper/describing/databases/ [accessed 30 May 2017] Considering also the simplicity and lack of refinement of the watermark design, it may be assumed that the paper was of medium or low value.

82 Fanny Davis, The Ottoman Lady: A Social History from 1718 to 1918 (Connecticut: 1986), 123; Azra Abadžić Navaey, “The Image of the 'Others' in the Zenân-Nâme”, unpublished paper, presented in the Second European Convention on Turkic, Ottoman and Turkish Studies, 14-17 September 2016, Hamburg.

83 E. J. W. Gibb, A History of Ottoman Poetry, Vol. IV 1700-1850 (London: 1905).

84 At the same time, items like the aigrette and Ottoman loose-fitting garments offered European women who followed Turquerie fashions an alternative style of magnificence and leisure, one that freed them from physical constraints (Bevilacqua and Pfeifer, 105). 
attributed to the Flemish painter Jean-Baptiste Vanmour (1671-1737), currently exhibited at the Benaki Museum in Athens (Catalogue Number ГE9039). ${ }^{85}$

\section{Interrogating Objects}

The object-based research approach is clearly challenging, not only because surviving objects of 18 th-century daily life in Ottoman Greece are limited in number, but also because accompanying documentation is practically nonexistent. Attempting to reconstruct the past in which these objects were used means that they must be interrogated and interpreted as deeply and rigorously as the written reports. ${ }^{86} \mathrm{~A}$ process less familiar and less tested than writing history on the basis of written records, working with objects requires a considerable leap of imagination, returning the artefact to its former life, engaging with it as generously, as poetically, as we can in the hope of winning the insights it may deliver, although the limits of what we can know with certainty should be acknowledged. ${ }^{87}$ However, a history through objects can never itself be fully balanced because it depends entirely on what happens to survive. ${ }^{88} \mathrm{Of}$ course, this may be equally said for written texts; a history through texts may not be fully balanced either. Occasional discoveries of objects from the past or formerly unknown archival material may lead to critical changes in our knowledge and perspective of past events. ${ }^{89}$

Despite the difficulties and limitations, hands-on, object-based research with a special focus on the lives of Greek women in the long 18th century presents highly exciting prospects. Such an analysis would move from the

85 An analysis of the work by Vanmour, who spent most of his career working for various ambassadors in Istanbul, reveals the complexity of his influences and processes. Although he composed his paintings to make sense to a European public, he also operated within a borrowed Ottoman pictorial repertoire (Bevilacqua and Pfeifer, 84-85).

86 MacGregor, xvi.

87 MacGregor, xvii-xviii.

88 MacGregor, xix.

89 The Black Sea Maritime Archaeology Project is a case in point. This large-scale, international project has recently discovered off the Bulgarian coast several shipwrecks spanning a millennium, from the Byzantine to the Ottoman times. These discoveries are expected to enrich our understanding of items transported along the Black Sea trade route, including furs, cloth, silk, satin, perfumes and jewels, as well as books and written documents. http://blackseamap.com [last accessed 20 December 2016], William J. Broad, "Explorers Find Lost World of Shipwrecks", The New York Times, 11 November 2016, http://www .nytimes.com/2016/11/12/science/shipwrecks-black-sea-archaeology.html?_r=o [accessed 30 May 2017]. 
materiality and tangibility of the object to a framework of information about itself and its relations to others. ${ }^{90}$ The history of goods cannot be understood without examining the ideas that accompany them. There can be no purely material history of objects: goods, practices, and ideas are inextricably linked. ${ }^{91}$ Following Klaus Krippendorff, our approach is based on the premise that the meanings that artefacts acquire in use are largely framed in language, therefore an independent theory of meaning of use is a conceptually convenient fiction. ${ }^{92}$ The meanings of objects are dialogical accomplishments that arise in the process of use and in the conversations between human beings, the present text being an example of such a conversation. Matter matters, but does not determine what human agents do with it; in this sense, artefacts cannot account for how they are being used and what they end up doing. Attributing agency to artefacts, as in actor-network theory, trivializes the concept of human agency. ${ }^{93}$ Therefore, objects are seen as expressions of human actions, not as actors themselves, and their meanings result from multiple descriptions by different users, bystanders or stakeholders, as well as from the ways in which objects are rearticulated or dropped out of the stories told, passed on, and performed. This approach encourages us to move from abstract objectivist theory to selfreflective human-centred accounts of our social worlds. ${ }^{94}$

Additionally, based on ideas put forward by Langdon Winner, one wonders about the consequences these objects have on the lives of people, especially on their sense of self, on the texture of human communities, on qualities of everyday living, and on the broader distribution of power in society. How do these objects transform personal experience, daily practices and social relations, especially with reference to women who have no voice and are consistently excluded from power? ${ }^{95}$ In this vein, this text attempts to establish a dialogue of sources about selected objects and the women who used them, seeking to create an entry point into the ways of living and thinking of these individuals who have remained largely silent in history.

\footnotetext{
9o Klose, 237 .

91 Bevilacqua and Pfeifer, 117.

92 Klaus Krippendorff, The Semantic Turn: A New Foundation for Design (Boca Raton FL: 2006), 147 .

93 Klaus Krippendorff, "Social Organizations as Reconstitutable Networks of Conversations", Cybernetics and Human Knowing, Vol. 15, nos. 3-4 (2008), 149-161.

94 Klaus Krippendorff. "The Dialogical Reality of Meaning", The American Journal of Semiotics, 19 (1/4) (2003): 17-34. http://dx.doi.org/10.5840/ajs2003191/41 [accessed 3o May 2017].

95 Langdon Winner, "Upon Opening the Black Box and Finding it Empty: Social Constructivism and the Philosophy of Technology", Science, Technology, and Human Values, Vol. 18, No. 3 (1993), 362-378.
} 


\section{Luxury, Prosperity, Identity}

The concept of luxury has been employed as a tool for the analysis of the objects under discussion. It is not easy to provide a broadly acceptable definition of the concept of luxury, which as a field of study has been largely neglected by historians and sociologists. Luxury may be defined as the production of exceptional objects, demonstrating an extraordinary investment in precious raw materials, craftsmanship, and time. At the beginning of the 21st century, emphasis is often placed on non-tangible forms of luxury, such as time or attention, which are scarce and much sought. In the long 18 th century, however, the idea of luxury was linked more closely to materiality. Creating luxury was an investment in expensive materials and in the labour required to make an object, including the long process of perfecting the necessary skills. ${ }^{96}$

While from a moral or philosophical point of view luxury is seen as a form of decadence, from an economic perspective it is seen as a force that drives consumption and the development of economy. In many cases, luxury is reserved to elite groups who show their power and pomp through the display of precious goods; the history of luxury may therefore be, from this perspective, a history of power, reflecting the syncretism of cultural and political thought. Luxury and fashion as components of material culture can also be analyzed through the lens of cultural history, since they play an important role in the creation of visual culture. ${ }^{97}$

Objects, especially imported ones, played a significant role in these processes. There was certainly a great variety of imported products in the Ottoman Empire and Greek communities had access to them through various commercial channels. The classic case-studies of 18th-century commerce at the ports of Thessaloniki (Salonica) and Izmir reveal the range of trade exchanges, especially from England, France, Venice and other Italian cities, the Netherlands, and Russia, as well as from outside Europe. A significant proportion of the imports consisted of items such as silks and brocades, watches, glass and porcelain, ${ }^{98}$ many of which would be cherished and used by women. Objects under discussion in this chapter, whether locally produced or imported, may be characterized as scarce (for example mirrors or musical instruments), which does not necessarily make them luxury objects. A toning-down of luxury might be appropriate, describing them as objects of value and perhaps examples of

\footnotetext{
$96 \quad$ What is Luxury?

97 LuxFaSS Research Project.

98 Svoronos; Frangakis-Syrett.
} 
recently achieved prosperity. Since the objects under consideration here belonged to members of the middle classes and not of the elite, it seems more likely that these items were not unique objects of luxury but rather beautiful, superfluous objects connoting affluence, comfort, a certain refinement of taste and possibly an inclination towards conspicuous consumption. These observations are especially relevant to one of the most striking features in the images studied, i.e. the fact that the women portrayed seem to be very much at ease, exuding confidence and a sense of well-being.

Attempting to understand these phenomena, we might ask the following questions: How was luxury understood in the context of 18th-century Greece and what were its manifestations? Is it possible to distinguish between different degrees or categories of luxury? Above all, what can we infer about Greek women owning and using scarce or luxurious items? What were the consequences of using such objects on women's social standing and sense of self?

The present investigation proposes the hypothesis that, for women of the Greek middle class in the 18th century, the consumption and use of objects of value in daily life operated as markers of an identity in the making. ${ }^{99}$ The aim of the research is to elucidate the ways in which the use of specific objects by Greek women, who were socially constrained by their gender and religion, was a mechanism for self-fashioning or even a method of transgression, where the individual may remake the rules and test the limits of authority. ${ }^{100}$ It may be possible to reconstruct the everyday world of these women by placing at the centre of our investigation objects such as the belt buckle, the comb, the mirror, the chest, the musical instrument and the book. Our object-based research approach focuses on specific 18th-century objects, material that is largely understudied and whose value remains unexplored. ${ }^{101}$ We expect that our research will contribute to increasing the visibility of women in the Ottoman Empire and will encourage the re-evaluation of historical events from the perspective of women. ${ }^{102}$ The guiding principle is the search for the underlying complexity, not for an idealized world of cultural synthesis. ${ }^{103}$

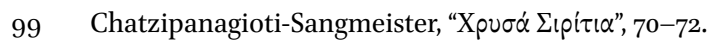

100 Madeline C. Zilfi, "Goods in the Mahalle: Distributional Encounters in EighteenthCentury Istanbul", in Consumption Studies and the History of the Ottoman Empire, 15501922-An Introduction, ed. Donald Quataert (New York: 2000), 289-311.

101 Handaka, 93-105.

102 İpşirli Argit, "Women in the Early Modern Ottoman World".

103 Eldem, "Greece and the Greeks", 28. 


\section{Conclusion}

This chapter has outlined an object-based approach to the material culture of middle-class Greek women in 18th-century Ottoman Empire. A preliminary exploration of selected types of objects and the establishment of a dialogue between visual, material, and written sources has demonstrated the potential of an object-based approach. The hypothesis put forward is that material possessions such as dress accessories, furniture, musical instruments or books were employed by Greek women in their attempts to construct a world of their own, where they could assert their individuality and enjoy themselves. The chapter suggests a departure from the elite concept of luxury towards ideas more appropriate to the emerging Greek bourgeoisie of the 18th century, namely affluence, prosperity, fashion awareness and joie de vivre. This diversion unravels promising research paths within the larger theme of the present volume on "Women, Consumption, and the Circulation of Ideas", as it points to a dynamic society which was open to influences and was actively cultivating and exploring new ideas. Additionally, by studying the lives of Greek women in the long 18th century, we may enhance our knowledge about the birth of Greek modernity and acquire a complex and more nuanced understanding of its numerous parameters. The research effort continues.

\section{Bibliography}

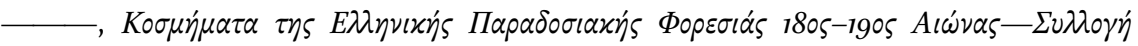

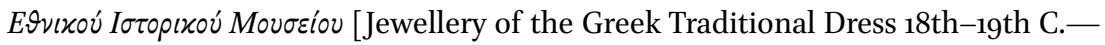
Collection of the National Historical Museum] (Athens: 1999).

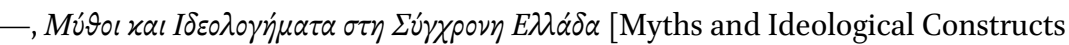
in Modern Greece] (Athens: 2007).

- LIMA: Watermark Databases, http://www2.warwick.ac.uk/fac/arts/ren/ archive-research/lima/paper/describing/databases, [accessed 30 May 2017].

— , LuxFaSS Research Project, http://luxfass.nec.ro [accessed 30 May 2017].

, Musical Instruments Museum Online, http://www.mimo-international.com/ MIMO/ [accessed 30 May 2017].

— , "Ottoman Music and its Instruments", http://www.turkishculture.org/music/ classical/ottoman-music-instruments-282.htm?type=1 [accessed 30 May 2017].

— , Podoabe Din Trecut, Colecţia de Paftale a Muzeului Naţional de Artă al României [Ornaments from the Past: Collection of Belt-buckles from the National Museum of Art of Romania], (Bucharest: 2015). 
, What is Luxury? Temporary Exhibition, Victoria \& Albert Museum, London, 25 April-27 September 2015.

Abadžić Navaey, Azra. "The Image of the 'Others' in the Zenân-Nâme”, unpublished paper, presented in the Second European Convention on Turkic, Ottoman and Turkish Studies, 14-17 September, Hamburg.

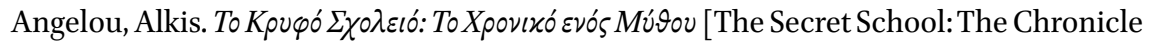
of a Myth] (Athens: 2007).

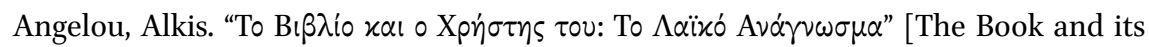

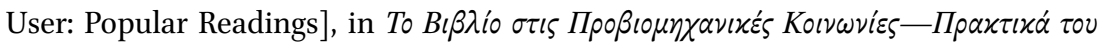

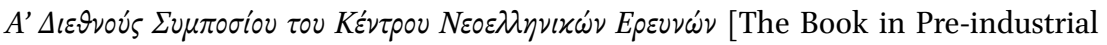
Societies-Proceedings of the 1st International Symposium of the Centre for Neohellenic Research] (Athens: 1982), 159-168.

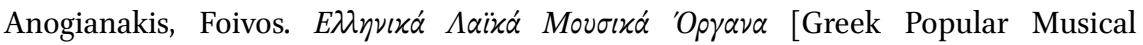
Instruments] (Athens: 1991).

Augustinos, Olga. French Odysseys: Greece in French Travel Literature from the Renaissance to the Romantic Era (New York: 1994).

Barbier, Frédéric. Le Rêve Grec de Monsieur de Choiseul: Les Voyages d'un Européen des Lumières (Paris: 2010).

Behar, Cem. "The Ottoman Musical Tradition", in Suraiya N. Faroqhi (ed.). The Cambridge History of Turkey, Volume 3: The Later Ottoman Empire, 1603-1839 (Cambridge: 2008), 393-407.

Betts, Gavin; Gauntlett, Stathis and Thanasis Spilias. Vitsentzos Kornaros, Erotokritos: A Translation with Introduction and Notes (Melbourne: 2004).

Bevilacqua, Alexander and Helen Pfeifer. "Turquerie: Culture in Motion, 1650-1750", Past and Present, no 221 (2013), 75-118.

Blake, Erin. "Learning to 'Read' Old Paper", http://collation.folger.edu/2012/o6/learning-to-read-old-paper/ [accessed 30 May 2017].

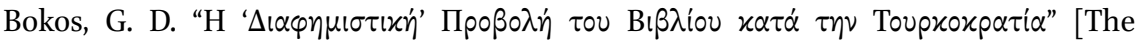

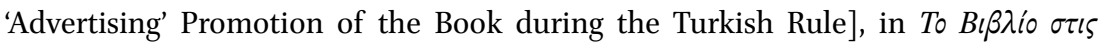

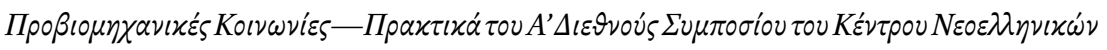

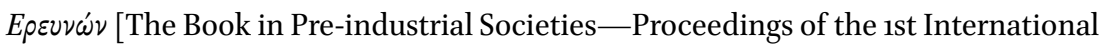
Symposium of the Centre for Neohellenic Research] (Athens: 1982), 113-136.

Broad, William J. "Explorers Find Lost World of Shipwrecks", The New York Times, 11 November 2016.

Burke, Peter. Eyewitnessing: The Uses of Images as Historical Evidence (London: 2001).

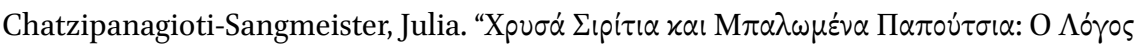

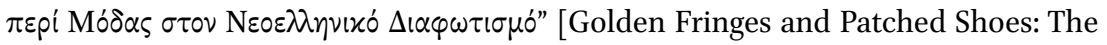
Discourse on Fashion in the Neohellenic Enlightenment], Ta Historika, vol. 62 (2015), 55-80. 


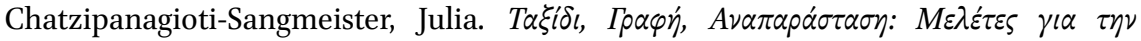

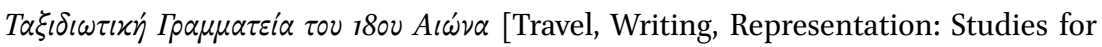
the Travel Literature of the 18th Century] (Athens, 2015).

de Choiseul-Gouffier, Marie-Gabriel-Florent-Auguste. Voyage Pittoresque de la Grèce (Paris: 1782).

Clogg, Richard. "Elite and Popular Culture in Greece under Turkish Rule", Indiana Social Studies Quarterly, vol. 32 (1979): 69-88.

Clogg, Richard. "The Greek millet in the Ottoman Empire", in Braude, Benjamin and Bernard Lewis (eds). Christians and Jews in the Ottoman Empire: The Functioning of a Plural Society I, The Central Lands, (New York: 1982), 185-207.

Coronelli, Vincenzo Maria, and Antonio Parissoti. Isola di Rodi. Geografica, Storica, Antica e Moderna, coll' altre adiacenti gia possedute da Cavalieri Hospitalieri di S. Giovanni di Gerusalemme. Opera de Padri Maestri Coronelli Cosmografo della Serenissima Republica di Venetia, e Parisotti Storiografo dell' Accademia Cosmografica degli Argonauti ..., (Venice: 1688).

Davis, Fanny. The Ottoman Lady: A Social History from 1718 to 1918 (Westport, Connecticut: 1986).

Dichtl, Erika. "Ein Leben für die Geschichte der Kostüm-Mode: Hermine von Parish", Neuhauser Werkstatt-Nachrichten, November 2012, 58-62.

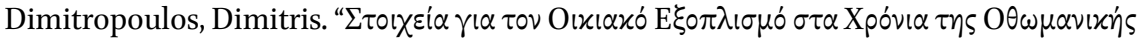

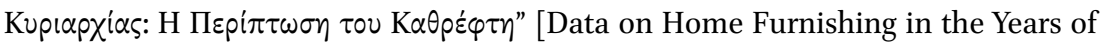
the Ottoman Rule], Ta Historika, vol. 13, no. 24-25, 1996, 37-62.

Eldem, Edhem. "Greece and the Greeks in Ottoman History andTurkish Historiography", The Historical Review/La Revue Historique, 6 (2009): 27-40.

Eldem, Edhem. "Capitulations and Western Trade", in Suraiya N. Faroqhi (ed.), The Cambridge History of Turkey, Volume 3: The Later Ottoman Empire, 1603-1839 (Cambridge: 2008), 281-335.

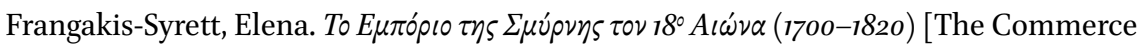
of Smyrna in the Eighteenth Century (1700-1820)], (Athens: 2010).

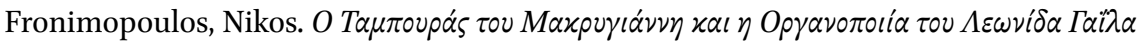
[Makriyiannis' Tambouras and the Instrument Making of Leonidas Gailas] (Athens: 2010).

Ghirardini, Christina. “Eyewitness' Accounts of Turkish Music and Dance in the Eighteenth Century", Imago Musicae XXVI (2013), 47-77.

Gibb, E. J. W. A History of Ottoman Poetry, Vol. IV 1700-1850 (London: 1905).

Göçek, Fatma Müge. Rise of the Bourgeoisie, Demise of the Empire: Ottoman Westernization and Social Change (New York: 1996).

Göçek, Fatma Müge. East Encounters West: France and the Ottoman Empire in the Eighteenth Century (New York: 1987). 
Handaka, Sophia. "The Objectification of History and the Historicizing of Objects: Understanding Neo-Hellenic Secular Art and Material Culture", in Kitromilides, Paschalis M. and Dimitris Arvanitakis (eds). The Greek World under Ottoman and Western Domination 15th-19th centuries, (New York: 2008), 93-105.

Handel, Stephan. "Die Mode-Sammlerin”, Süddeutsche Zeitung, 14 April 2009.

Hartlaub, Gustav Friedrich. Zauber des Spiegels: Geschichte und Bedeutung des Spiegels in der Kunst (Munich: 1951).

Hermanski, Susanne. "Schöne Hüllen gegen böse Geister", Süddeutsche Zeitung, 17 April 2007, 45.

İpşirli Argit, Betül. "Women in the Early Modern Ottoman World: A Bibliographical Essay”, Akademik Araştilmalar Dergisi 6o (2014): 1-28.

İpşirli Argit, Betül. "Visual Material as a Source for the Study of Ottoman Women in the Early Modern Era", in: Türe, D. Fatma and Birsen Talay Keşoğlu (eds). Women's Memory: The Problem of Sources, (Newcastle upon Tyne: 2011), 29-39.

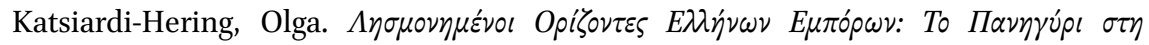

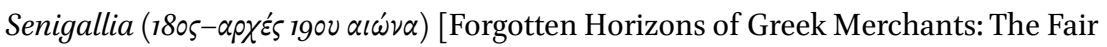
in Senigallia (18th-early 19th c.)](Athens: 1989).

Klose, Alexander. The Container Principle: How a Box Changes the Way We Think (Cambridge MA: 2015).

Krippendorff, Klaus. "Social Organizations as Reconstitutable Networks of Conversations", Cybernetics and Human Knowing, Vol. 15, nos. 3-4 (2008), 149-161.

Krippendorff, Klaus. The Semantic Turn: A New Foundation for Design (Boca Raton, Florida: 2006).

Krippendorff, Klaus. "The Dialogical Reality of Meaning", The American Journal of Semiotics, 19 (1/4) 2003, 17-34. http://dx.doi.org/10.5840/ajs2003191/41 [accessed 30 May 2017].

Laiou, Sophia. "The Ottoman Greek 'Merchants of Europe' at the beginning of the 19th Century", in Evangelia Balta, Georgios Salakidis and Theoharis Stavrides (eds). Festschrift in Honor of Ioannis P. Theocharides. Studies on the Ottoman Empire and Turkey, vol. II, (Istanbul: 2014), 313-331

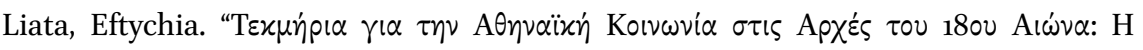

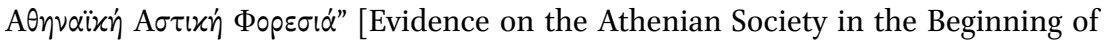
the 18th Century], Mnēmon, 11, 1987, 32-53.

Lilić, Vladislav. "The Conquering Balkan Orthodox Merchant, by Traian Stoianovich. The Journal of Economic History, vol. 20, no. 2, June 1960, 234-313", https://global historyreview.wordpress.com/2015/03/21/the-conquering-balkan-orthodox -merchant-by-traian-stoianovich-the-journal-of-economic-history-vol-2o-no -2-june-1960-pp-234-313/ (Article Review) 2015 [accessed 30 May 2017].

MacGregor, Neil. A History of the World in 100 Objects (London: 2012), 


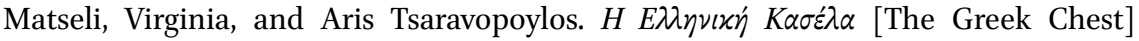
(Athens: 2010).

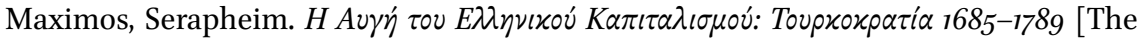

Dawn of Greek Capitalism: Turkish Rule 1685-1789] (Athens, 2008).

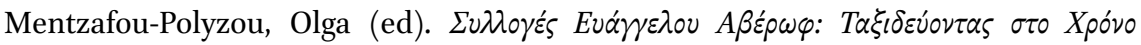

[Evangelos Averoff Collections: Travelling in Time] (Athens: 2000).

Moises, Jürgen. “Dem Zeitgeist auf der Spur”, Abendzeitung, 18 April 2007.

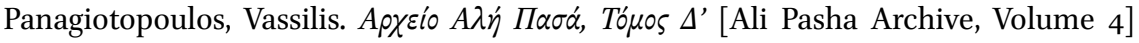
(Athens: 2009).

von Parish, Hermine. "Bibliothek und Dokumentation des Kostümforschungsinstituts von Parish in München", Bayern BFB, vol. 18 (3) (Munich: 1990), 302-311.

Parshall, Peter. "Prints as Objects of Consumption in Early Modern Europe", in:Journal of Medieval and Early Modern Studies, vol. 28 (1998): 19-36.

Peltre, Christine. Retour en Arcadie: Le Voyage des Artistes Français en Grèce au XIX Siècle (Paris: 1997).

Peters, Gabi. "Wo der Modezar am Bananenrock Schnüffelt”, Bayerische Staatszeitung, no 36, 7 September 2007.

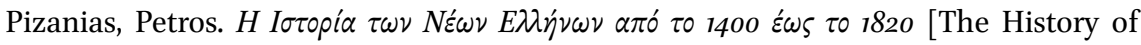
Modern Greeks from 1400 to 1820] (Athens: 2014).

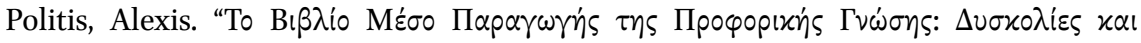

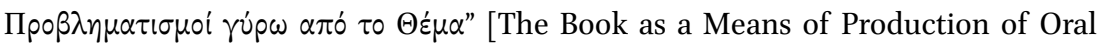

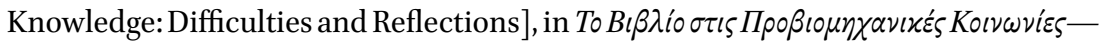

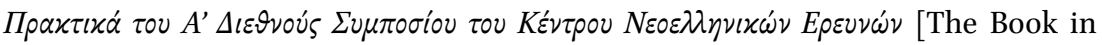
Pre-industrial Societies-Proceedings of the 1st International Symposium of the Centre for Neohellenic Research] (Athens: 1982), 271-282.

von Stackelberg, Otto Magnus. Trachten und Gebräuche der Neugriechen, (Berlin: 1831). Stafford, Barbara Maria and Frances Terpak. Devices of Wonder: From the World in a Box to Images on a Screen (Los Angeles: 2001).

Stoianovich, Troian. "The Conquering Balkan Orthodox Merchant," The Journal of Economic History 20 (1960), 234-313.

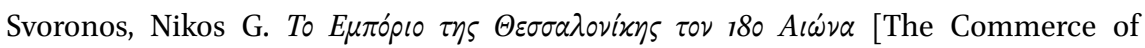
Thessaloniki in the 18th Century] (Athens: 1996).

de Tournefort, Joseph Pitton. Relation d'un Voyage du Levant, fait par ordre du Roy. Contenant l'histoire ancienne \& moderne de plusieurs Isles de l'Archipel, de Constantinople, des côtes de la Mer Noire, de l'Armenie, de la Georgie, des frontières de Perse \& de l'Asie Mineure. Avec les plans des villes \& des lieux considérables ..., t. I, (Paris: 1717).

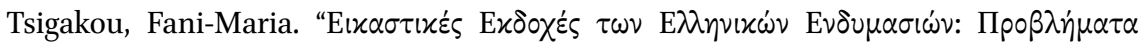

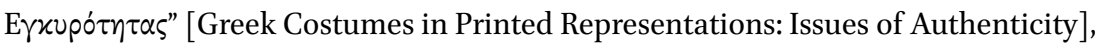




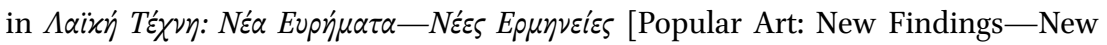
Interpretations], ed. Handaka Sophia (Athens: 2015), 81-90.

Van Der Woude, Ad and Anton Schuurman. Probate Inventories: A New Source for the Historical Study of Wealth, Material Culture and Agricultural Development (Wageningen: 1980).

Vingopoulou, Ioli. Travelogues, 2014, http://eng.travelogues.gr, Aikaterini Laskaridis Foundation [accessed 30 May 2017].

Winner, Langdon. "Upon Opening the Black Box and Finding it Empty: Social Constructivism and the Philosophy of Technology", Science, Technology, and Human Values, Vol. 18, No. 3 (1993), 362-378.

Zilf, Madeline C. (ed.). Women in the Ottoman Empire: Middle Eastern Women in the Early Modern Era (Leiden: 1997).

Zilf, Madeline C.(ed.). "Goods in the Mahalle: Distributional Encounters in EighteenthCentury Istanbul”, in Consumption Studies and the History of the Ottoman Empire, 1550-1922-An Introduction, ed. Donald Quataert (New York: 2000), 289-311. 